\title{
The Monds and Chemical Industry: a Study in Heredity.
}

"I propose to present his character and story with this object: to cite him as the great example of those who do mightily yet cannot see what they are doing and who stand on the edge of doom with no vision of its approach." -Wolsey: Hilaire Belloc.

" $\mathrm{T} N$ this world, one is too frequently approved or disapproved without being understood." This remark is passed by the Japanese professor of art, Yukio Yashiro, in the preface to the new edition of his opulent work on "Sandro Boticelli", in discussing criticisms aimed at his book. Is it possible to understand any complex personality to the point of being able to " approve" his actions, by analysing them to their origin? Prove, German priifen, is a very difficult verb to apply, at least in English; in German, it is without ambiguity.

Some day, perhaps, biography will be written almost in terms of structural chemistry and the doctrine of descent stated in terms of the permutations and combinations effected between genes: then, types, structural units, will be dissected out. It is fast becoming clear that even the most complex of natural molecular units are but repetitionals: that they are built up of simple parts frequently repeated. The candle is a fit emblem of its substance: as it may be made of any length, burnt to any shortness; to the mind's eye, it is the like of the Roman Fasces, in contexture. When, at last, we see ourselves as chemists shall see us, the most wonderful imprint of pattern will be displayed upon our skins. Maybe the analysis will not be possible before 'Jeansery' is at its last gasp and we are about to dissolve into radiation. Still, suspicions of structure are already held by some of us.

I merely wish to claim, in all modesty, that biography should be the recognised province of the structural chemist: he alone can appreciate the complete interdependence of character and structure. The supreme interest of chemistry comes from the fact, that it is the study of character as affected by structure. Our senses seem to be but distortions of structure and electrical ripplespurely physical 'emotions'. Witness the Poulsen phonograph, in which a steel tape is drawn across the magnetic field of the telephone: returning the tape against the way it came, we have speech reproduced. The tape hears and remembers what it hears; can tell what it has heard: it all but lives! It is so human that it also forgets. We cannot doubt that the molecules of the metal are displaced when magnetically spoken at, that they remember by retaining the new positions imparted to them, that speech is the molecular click as they revert to their original positions. Seeing that 'wireless' can hit us as it does, there is no difficulty in understanding that we cannot but respond to every impression from outside.

We need to be far more observant of hereditary character. The Mond family seems to me to be specially deserving of study in this connexion. Seldom has the biographer had the opportunity I have had of observing both father and son through. out their whole career of public activity. I first met Ludwig Mond when his son Alfred was only three or four years old, in the early 'seventies. The parents were cousins ; their two sons, Robert and Alfred, have always seemed to me to be near hybrids but with a clear bias from the mother. The father was a man of very strong and determined character, almost rough originally; the mother, a woman of peculiar sweetness and sanity of outlook.

Alfred Mond was born when a touch of sulphur was still lingering in the air, under a just ascending star, a true nova of the first magnitude in industrial progress. Growing up in an environment of strongly alkaline $p \mathrm{H}$. he was to develop throughout the $p$ gamut, ever progressing, first as politician of changing hue, from a radical bright red to a mild conservative blue, then as 'company combiner', until at last he became not merely leader as an industrial magnate but an industrial statesmanthe first of his kind. No more interesting man has trodden the stage of public life during his period. In heredity and environment, he was subject to exceptional influences: probably he had no peer, at least in his later days, when again the $p$ 's come in. He was a peculiar being, maybe the forerunner of a new type: the politician with intelligence, fully alive to the value and use of knowledge, even in the affairs of government: as far from the demagogue as he possibly could be : hence possibly the antagonism between him and Mr. Lloyd George, let us hope the last representative of an expiring crude and unscientific civilisation.

Ludwig Mond, his father, came to England fully prepared, both by German education and Dutch experience of the alkali trade, for the work he undertook-aflame with the pioneering spirit and full of masterful energy. He brought with him a process for the recovery of sulphur from alkali waste, then a nuisance as well as a by-product. This did not carry him far. Hearing of Ernest Solvay's invention of an improved and novel process of making soda from salt, without sulphuric acid, he went over to Belgium and was just in advance of another claimant, Walter Weldon, in securing the English rights to work the invention. As Mrs. Mond told me more than once, he was ambitious, even in those early days, to play the part of the constructive pioneer, to be original, not merely to make money. Originality, we have been told, consists in thinking for yourself, not merely in being different from others: Ludwig Mond, in this respect, was most original. He also knew his own limitations-that ' business' was not his forte: so he sought out the ablest business man within his reach and found him in (Sir) John Brunner. They were a perfect pair-one looked after the pounds in the works, the other after the pence in the office. Mond secured a mere sketch from Solvay : a vast amount of detailed work was necessary to bring the process to perfection ' it was full of difficult engineering minutiæ. Taking off his coat, spanner in hand, he himself tightened up each bolt until the last leak of ammonia was overcome. The ammonia-soda process was thus 
quickly established, almost in its full perfection : Mond was soon seen to be a destroying angel on Tyneside as the firm rapidly came to the fore. The old Le Blanc process was mainly kept alive for its by-products.

Ludwig Mond left Germany years before the time when the laboratory became a fashionable and necessary adjunct to the works-the source of advance, not merely a control station. He also never followed the German system of giving members of the staff an interest in improvements or discoveries they might make. Perhaps on this account the works remained an ammonia-soda works. Still, his own mind was at work, seeking fresh fields to conquer. Thinking in terms of ammonia, he was led, in the middle 'eighties, to take up the gasification of coal, largely with the object of recovering its nitrogen as ammonia. $\mathrm{He}$ established large works at Dudley Port, from which producer-gas was supplied to the surrounding district. The enterprise has not been the economic success that was expected, the more as conditions have changed to its disfavour-especially, of late, owing to the rise in the price of coal and the introduction of synthetic ammonia, which has much lowered the value of scrubbed ammonia. It is strange how little success has attended all tampering with coal-except at the hands of the gas companies, who have known how to roast it hard: all low temperature attempts have been economic failures and probably will remain so, at least until effective means of cleaning coal from dirt be devised. Still, Mond's experiment has been of remarkable interest in many ways, as it has involved producing and carrying vast quantities of gas long distances at controlled rates, without use of holders. The control secured is altogether surprising, on account of the scale of working. Also, a hive of 'small industries' has been established.

Had not Mond made what to me always seemed to be a blunder by burning coal to a weak gas, thinking its nitrogen to be of sufficient economic value to be worth recovery, although this involved the sacrifice of the tar, I believe he would have taken up the low temperature distillation of coal himself. I had brought the subject before the Iron and Steel Institute in 1885 and had almost persuaded him to undertake an intensive study of coal, when suddenly he became over-excited by thoughts of ammonia. Had he done so, he would have carried out the inquiry scientifically and thoroughly : thirty years ago, probably, we should have known where we were, and the public would never have been gulled into believing in the commercial possibility of oil from our coal. Undoubtedly, a vein of idealism now began to be apparent in him. He had little real feeling for coal as a substance, not being an organic chemist, nor had he specially directed his attention to fuel problems, although ever mindful of the need of preventing waste of energy. Probably, he went out of his depth.

At this time Mond's ever active mind embarked en fresh quest. Mindful of the great loss of energy involved in the use of solid fuel, he sought to develop the Grove hydrogen-oxygen, sulphuric acid, platinum, gas cell : again perhaps a stroke of idealism. For this purpose, he needed hydrogen in large quantity. The only economic source was 'water-gas', the mixture of hydrogen and carbonic oxide produced by passing steam over heated carbon (anthracite). It was necessary to remove the carbonic oxide, a virulent poison to platinum. He used a known method, which involved passing the mixture of gases over heated nickel. In experiments carried out in his laboratory, in St. John's Wood, his assistant, Dr. Quincke, to prevent the passage of the poisonous carbonic oxide into the air, put the end of the escape tube from the apparatus into the air hole at the base of a Bunsen burner. He noticed that the gas burnt with a smoky flame-evidently there was some volatile product. Mond not only at once followed up this indication to the quick discovery of nickel carbonyl, $\mathrm{Ni}(\mathrm{CO})_{4}$ : finding this was easily resolved into nickel and carbonic oxide by heat, he forth. with developed a continuous reversible process for the manufacture of nickel on the large scale. $\mathrm{He}$ was greatly assisted by Dr. Langer, one of Victor Meyer's most able pupils. The achievement is without precedent in the history of scientific manufacturing enterprise, in virtue of its originality, the rapidity with which it was conceived and the in. trepidity with which it was executed.

Ludwig Mond, therefore, was the founder of at least three industrial enterprises-two of them are great and highly successful and likely to be permanent. He knew his subject: he had practical chemistry in his bones, if ever man had. Ever a thinker and worker, a man of action, never a man of words-he wrote no letters apart from business - he was highly cultured: a good linguist, an art patron, himiself a good judge. From boyhood up, Mrs. Mond had led him in literature and art. She was an idealist of the first water, saturated with Goethe. Their daily life was perfect.

The son's career was very different. He had not the advantage of a serious German education. At school and university, he will not have been overtaught: he was never spurred to special effort, as his father was, in order to make his way. From an early age, brought up in a specially cultured society, using his own great innate ability, he himself became a man of considerable culture. He read law but never entered into practice. So far as I know, he had merely gathered impressions of natural science and had no affinities to it, differing in this respect from his elder brother, who has considerable knowledge of physical science and experimental proclivities.

The son of parents situated as his were had no cause to exert himself. He gradually became the politician, perhaps, too strong a radical to please his father. Here probably he was greatly influenced by the late Sir John Brunner, an ardent politician. In the House of Commons, a speaker of weight, he was so clear-headed, so well informed, so obviously a thinker of unusual breadth and sanity, that he soon acquired distinction. In political office, he showed real administrative ability. That he had a scientific mind was shown by his gradual 
change in political outlook and his change of party. Of course, for party purposes, a man must resist the influence of intelligence and stick to his party but it is only from this point of view that change of party is to be deprecated ; actually, it is proof of strength and individuality - in no way discreditable.

In a measure, his translation to the Upper House, in 1928, probably in no way satisfied his ambition and was a disappointment, marking as it did the close of his political career. He had aspired to the highest office, beyond doubt, but pronounced idiosyncrasies of manner were against him: he was outwardly ' too foreign' to be acceptable. To satisfy his aspiration, in his later years, he devoted himself to industrial rather than to political statesmanship. The spirit of idealism, which I have spoken of as actuating the father, became greatly operative in the son. He showed himself to be gifted with a co-ordinating mind, whilst his father had been constructive. He entered into a discussion of the problems of labour and in the interests of ' rationalisation'-to use the fashionable word of the day-effected two great industrial combines. Whatever assistance he may have had, there is no doubt that his was the guiding spirit, his the driving force. To come back to chemistry, while the father was a true chemist, a highly original worker, who really made things, the son was like the modern physical chemist, who is more or less a visionary and a speculator in other people's works, not a worker himself. Apparently, the one cannot be the other. Some of us contend that the physical chemist does not know enough chemistry to justify the certainty of his opinions. It is a question whether Alfred Mond knew enough to deal with issues and problems of the complexity and magnitude of those he undertook. Although scientific in his outlook, a systematic user of knowledge, he knew nothing of experimental and physical science and cannot have had any real feeling for the industries with which he was connected.

In effigy to-day he commands an Imperial position in Chemical Industries - his father on his right hand. By a strange turn in the wheel of fortune, he was led to develop, on a colossal scale, the manufacture of ammonia from atmospheric nitrogen by the Haber-Bosch process, so taking a step commercially antagonistic to his father's perhaps most favoured enterprise: ruinous also to the Chile nitrate industry. It may be that one good turn deserves another : industrial progress, so-called, too often seems to involve the supercession of earlier workers. The grave economic, political issue of the present universal industrial rush to our atmosphere, however, has yet to be apparent. To make the inert active is always dangerous, if not an impiety; it may well be a jump from frying-pan into a burning fiery furnace of soil destruction.

Father and son probably could never have exchanged places: they were different natures. Ludwig Mond kept pretty well within the limits of his abilities and sought competent assistance when going outside them: to decide to what extent the son was Napoleonic and overstepped his, will not be easy. One thing is certain, that like his father before him, he gave his full strength to whatever service he undertook. Opinions greatly differ as to the wisdom of his action-as to the competency of a system such as he sought to develop. On account of the growing gravity of the industrial situation, the absolute need of completely scientific management-in other words, of complete understanding - a full inquiry into the problem of control should be undertaken with all possible care and without delay. The matter is already engaging attention abroad and such discussion is therefore of immediate national importance to us. It cannot be undertaken by men of affairs alone-they have not the necessary breadth of knowledge,

Much is said of academic research as the mainstay of industry and industry is being called upon to give support to the work. At the moment, there is great waste of energy and of funds, both national and private, on account of lack of co-ordination and clear-cut views as to the purpose of the workparticularly because of the lack of competent supervision. The great need in industry of full inquiry into the efficiency of the methods followed in its own management and conduct has yet to be recognised : in such direction, industrial research is imperative.
Henry E. Armstrong.

\section{Southern Whales and Whaling.}

$\mathrm{T}$ HE Discovery Committee appointed in 1923 as a result of the findings of the Interdepartmental Committee on Research and Development in the Dependencies of the Falkland Islands is now issuing, under the general heading of " Discovery Reports ",* a series of reports by the Committee's

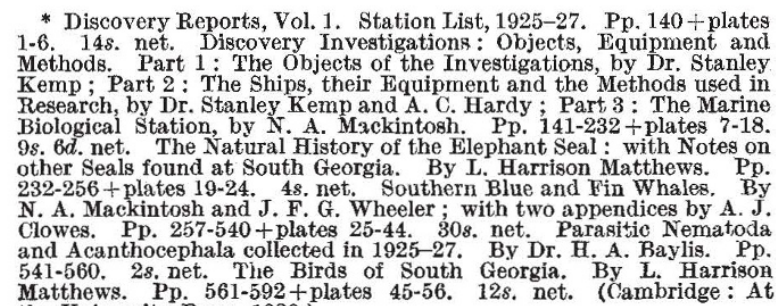
the University Press, 1929.)

No. 3198 , Vou. 127] scientific staff and others on the investigations being carried out in the southern hemispheremainly regarding the scientific aspect of whales and the whaling industry. As in other recent expeditions, the reports are not published in any definite sequence of subject, but as the different stages of the work are completed. The advantages of this procedure are obvious.

The principal industry of the Falkland Islands is whaling, and, since the inception of commercial operations in 1904, there has been a rapid rise in the success of the industry. The history of whaling operations in other parts of the world has acted as a powerful stimulant, both to the administrative controllers of the Dependencies and to scientific experts, to gauge the effects of excessive slaughtering of 